\title{
A new species of Rubus (Rosaceae) from Arunachal Pradesh, India
}

\author{
C. Gupta ${ }^{1}$, S.S. Dash ${ }^{2}$
}

\section{Key words}

India

new taxa

pollen morphology

Rosaceae

Rubus

subgenus Malachobatus

\begin{abstract}
A new species, Rubus ramachandrae, from Upper Subansiri district of Arunachal Pradesh, India is described and illustrated. It is closely similar to $R$. stipulosus and $R$. fuscifolius but differs by densely bristly or hirsute branches; narrowly ovate or oblong-lanceolate leaves with caudate-acuminate apex and adaxially hirsutulous vesture; abaxially grey tomentose intermixed with hirsutulous hairs; larger size of stipules and bracts with distinct margin and vesture; smaller size of floral structure. The distinct foliar as well as floral morphology of $R$. ramachandrae differs from all previously described species of Rubus. Differences in key morphological characters of $R$. ramachandrae, $R$. stipulosus and $R$. fuscifolius are also tabulated. In addition, pollen morphology is described based on light (LM) and scanning electron (SEM) microscopy. Based on the presence of straggling shrubby habit, free stipules, simple leaves, reflexed and strong needle shaped prickles, the new taxon is assigned to Rubus subg. Malachobatus. An image of the type specimen; digital images of habit, stipule, inflorescence and flower, a detailed illustration and scanned electron microscope images of pollens are provided.
\end{abstract}

Published on 7 May 2018

\section{INTRODUCTION}

Rubus L. (1753: 492) (Rosaceae) is represented in India by about 75 species (Gupta \& Dash 2015) distributed principally in dense primary to secondary tropical forests to temperate regions at altitudes between 300 and $3500 \mathrm{~m}$. In India the greatest diversity of the genus is in the eastern Himalayan states of Arunachal Pradesh and Sikkim (Gupta et al. 2016). Rubus exhibits great morphological variation in its habit, foliar and floral structure (Naruhashi 1980, Kalkman 1993).

During field exploration in Arunachal Pradesh, India we came across interesting individuals of Rubus in a subtropical forest in Upper Subansiri district. Critical examination of the specimen and comparison with specimens of Rubus in all major herbaria (APFH, ARUN, ASSAM, BLATTER, BSD, BSHC, BSI, CAL, DD, $\mathrm{MH}, \mathrm{NBU}$ and $\mathrm{PBL}$ ) of India revealed no possible match with any other species. We also compared the specimen against images of Rubus from multiple international herbaria (A, BM, $\mathrm{K}, \mathrm{L}, \mathrm{LINN}, \mathrm{MO}, \mathrm{NY}, \mathrm{P}$ and PE) and concluded that the plants from Upper Subansiri are morphologically different from all known species of Rubus. We here name these plants Rubus ramachandrae S.S.Dash \& Chand.Gupta.

\section{MATERIALS \& METHODS}

The description of $R$. ramachandrae is based on living specimens collected during our field survey in Upper Subansiri district of Arunachal Pradesh, India and subsequent observations on herbarium specimens. Based on previous revisionary and systematic works (Focke 1910, 1911, 1914, Smith 1819, Roxburgh 1832, Hooker 1878, Kuntze 1879, Kanjilal et al. 1922, Long 1987, Kalkman 1993, Lu \& Boufford 2003, Boufford et al.

\footnotetext{
${ }^{1}$ Central National Herbarium, Botanical Survey of India, Howrah - 711 103, West Bengal, India.

${ }^{2}$ Botanical Survey of India, CGO Complex, Salt Lake City, Kolkata - 700 064, West Bengal, India;

corresponding author e-mail: ssdash2002@gmail.com.
}

2011) and regional floristic works (Sharma \& Kachroo 1981, Chowdhery \& Wadhwa 1984, Chowdhery et al. 1996), it was compared with the most morphologically similar species, Rubus stipulosus T.T.Yu \& L.T.Lu and R. fuscifolius T.T.Yu \& L.T.Lu . Micro-morphological characters of the pollen of $R$. ramachandrae was examined using a scanning electron microscope (SEM, model FEl Quanta 200) at HV 20.0 EV and under oil objective (100x) using an Olympus CX41 light microscope at the Central National Herbarium, Howrah. Pollen characters were described following Erdtman $(1943,1952)$ and Punt et al. (2007). The morphological characters of $R$. ramachandrae were compared with the digital images of $R$. stipulosus and $R$. fuscifolius (both at $\mathrm{PE}$ ) in combination with the respective protologues and literature (Yu \& Lu 1982, Lu \& Boufford 2003). Details are provided in Table 1. An image of the type specimen (Fig. 1); digital images of the habitat, stipule, inflorescence and flower (Fig. 3), an illustration (Fig. 2) and scanned electron microscope images of the pollen (Fig. 4) are provided. Extensive field trips were undertaken in various localities of the eastern Himalaya during the present revisionary study of Indian Rubus.

\section{Rubus ramachandrae S.S.Dash \& Chand.Gupta, sp. nov. - Fig. 1-4; Map 1}

Rubus ramachandrae is similar to Rubus stipulosus and $R$. fuscifolius, but differs by having densely bristly or hirsute branches; narrowly ovate to oblonglanceolate leaves with caudate-acuminate apex; adaxially hirsutulous vesture of leaves; broadly ovate to suborbicular, foliaceous, persistent stipules with irregularly and deeply biserrate margin; hirsutulous and fulvous-tomentose floral bracts and obovate petals. - Type: S. S.Dash \& Chandani Gupta 65482 (holo CAL; iso CAL, ARUN, ASSAM), India, Arunachal Pradesh, Upper Subansiri district, between Daporijo and Raga village, E94 ${ }^{\circ} 11^{\prime} 42.5$ N27 $49^{\circ} 23.4$, 1270 m alt., 15 Aug. 2015. - Paratype: S. S. Dash \& Chandani Gupta 67403 (BSD, CUH), near La village, $35 \mathrm{~km}$ from Daporizo, E94 ${ }^{\circ} 13^{\prime} 32.3$ N27 $51^{\circ} 142.7$, $1260 \mathrm{~m}$ alt., 9 Aug. 2016.

Etymology. The species is named in loving memory and reverent regards of Sri Rama Chandra Dash, father of corresponding author, who was a constant source of encouragement and motivation during all field work in the difficult terrain in Arunachal Pradesh.

\section{(C) 2018 Naturalis Biodiversity Center}

You are free to share - to copy, distribute and transmit the work, under the following conditions:

Attribution: $\quad$ You must attribute the work in the manner specified by the author or licensor (but not in any way that suggests that they endorse you or your use of the work). 
Table 1 Morphological comparison between Rubus ramachandrae and its allied species.

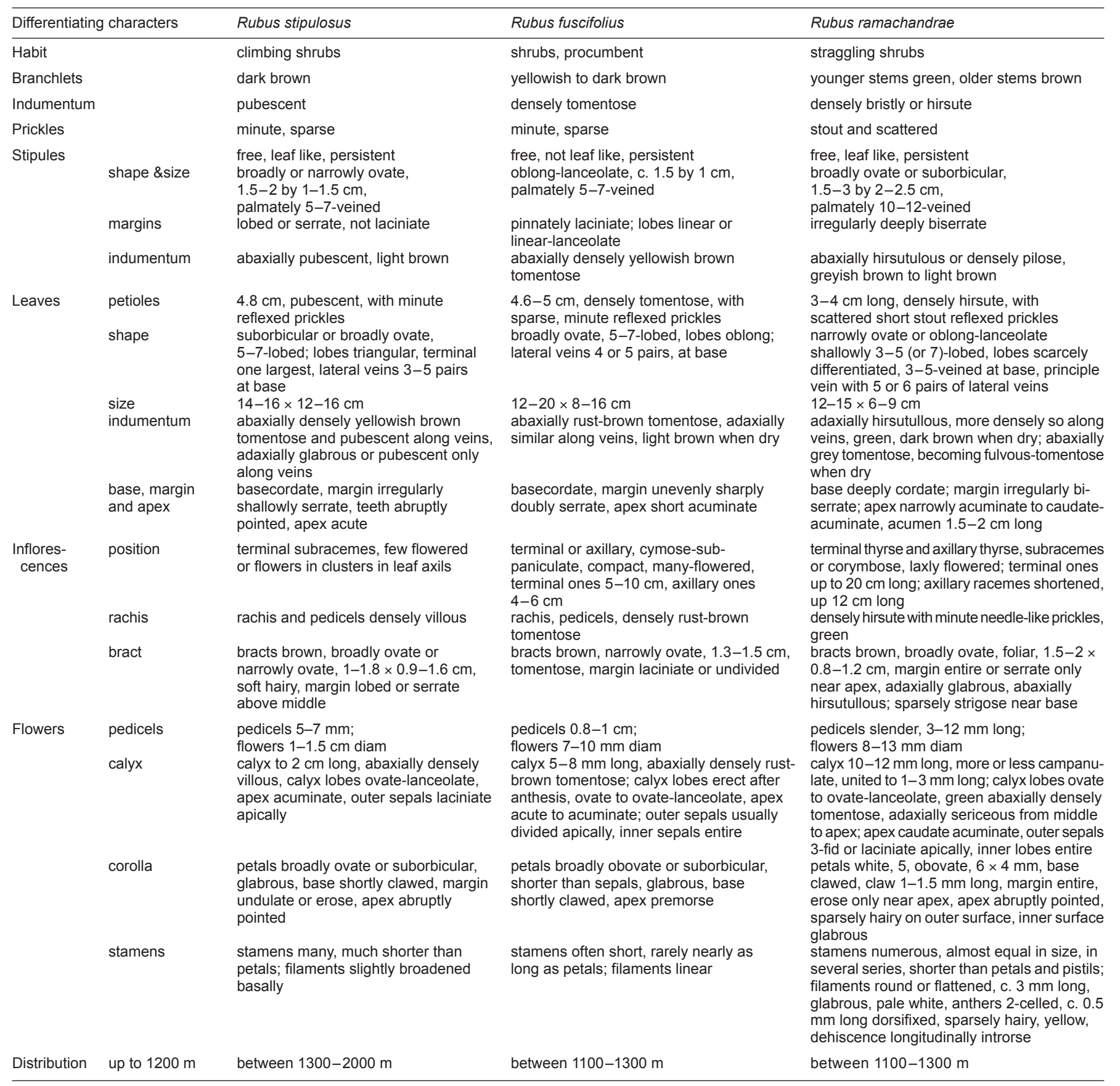

Shrubs, straggling, to $3 \mathrm{~m}$ tall. Stems terete, erect or procumbent, woody, densely bristly or hirsute mixed with reflexed strong prickles, green, bristles white becoming brown in age, internodes $4.5-6 \mathrm{~cm}$ long. Stipules foliar, broadly ovate to suborbicular, $1.5-3$ by $2-2.5 \mathrm{~cm}$, apex acute, margin irregularly deeply biserrate, glabrous adaxially hirsutulous or densely pilose abaxially, brown, palmately 10-12-veined, persistent or rarely late caducous. Petioles slender, $3-4 \mathrm{~cm}$ long, densely hirsute, with short stout reflexed prickles, green. Leaves alternate, simple, narrowly ovate or oblong-lanceolate, shallowly 3- or 5- (or 7-)lobed, lowest two lobes often differentiated, upper lobes scarcely differentiated, $12-15$ by $6-9 \mathrm{~cm}$, apex narrowly acuminate to caudate-acuminate, acumen $1.5-2 \mathrm{~cm}$ long; apex of lobes acute, margin irregularly biserrate, constricted at lobes; base deeply cordate, 3-5-veined at base, principle vein with 5 or 6 pairs of lateral veins; adaxially hirsutulous, more densely so along veins, green, dark brown when dry; abaxi- ally grey tomentose, becoming fulvous-tomentose when dry. Inflorescences terminal thyrse and axillary thyrse, subracemose or corymbose, terminal inflorescences up to $18 \mathrm{~cm}$ long, more than 20-flowered, axillary inflorescences shortened, 5-12 cm long, laxly flowered; rachis hirsute, mixed with minute needle shaped prickles; involucral bracts 2 , foliar, $1.3-1.8$ by $0.8-1.2$ $\mathrm{cm}$, broadly ovate, apex acute, margin serrate or serrate only near apex, adaxially glabrous, abaxially hirsutulous; sparsely strigose near base, brown; pedicels slender, 3-12 mm long, subtended by 2 floral bracts, hirsute; ovate or ovate-oblong, $4-10$ by $1-8 \mathrm{~mm}$, almost covering the buds, apex acute, margin entire or with very few serrations apically, abaxially densely pubescent to hirsutulous, mixed strigose at base, adaxially glabrous, green, brown at maturity. Flowers bisexual, actinomorphic, 0.8-13 $\mathrm{mm}$ across; hypanthium perigynous; calyx green, more or less bell-shaped or narrowly campanulate, united at base to 1-3 mm long, lobes 5, ovate to ovate-lanceolate, 10-12 


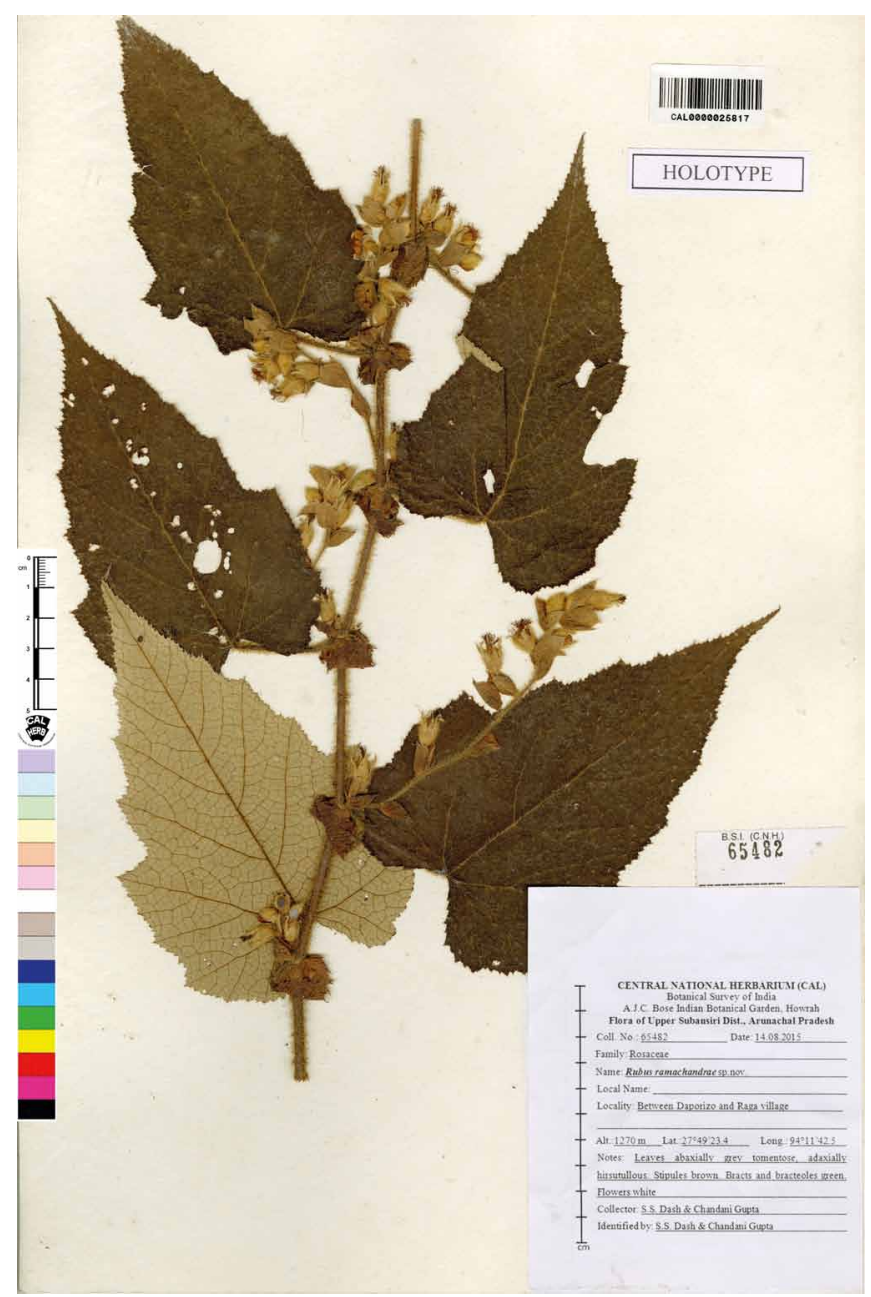

Fig. 1 Image of holotype of Rubus ramachandrae S.S.Dash \& Chand.Gupta.

by 3-4 mm, apex caudate-acuminate, outer lobes 2- or 3-fid or laciniate, inner lobes entire, abaxially densely tomentose, adaxially sericeous from middle to apex, margin of outer lobes with white hairs; petals white, 5 , obovate, 6 by $4 \mathrm{~mm}$, base clawed, claw 1-1.5 mm long, margin entire, erose only near apex, apex abruptly pointed, sparsely hairy on outer surface, inner surface glabrous; stamens numerous, almost equal in size, in several series, shorter than petals and pistils; filaments round or flattened, c. $3 \mathrm{~mm}$ long, glabrous, pale white, anthers 2-celled, c. $0.5 \mathrm{~mm}$ long, dorsifixed, sparsely hairy, yellow, dehiscence longitudinally introrse; carpels many, ovary lunate, c. $1 \mathrm{~mm}$ long, glabrous, short stalked, style subterminal, c. $1 \mathrm{~cm}$ long, glabrous, white, stigma capitate, torus convex, to $2 \mathrm{~mm}$ long, with few stiff hairs basally.

Pollen morphology - Pollen grains 3-colporate, prolatespheroidal (P/E ratio: 1.04) 24-25 $\mu \mathrm{m}$ in polar length with rounded, often emarginate ends, colpus narrow, distinctly uniform along the poles, extending over $90 \%$ of the polar axis, equatorial bridge distinct, margins constricted at equator and elevated. The colpus membrane is covered with rugged granulations and undulate. The endoaperature is smooth, indistinct and usually hidden under the rugged exine or equatorial bridge. The exine layer is thick and finely ornamented. The surface ornamentation is finely verrucose-foveolate. The punctum consists of more or less rounded depressions and narrow and often anastomosing elongated verrucae, more often creating a perforated suprarugulate tectum (Fig. 4).

Distribution - India, Arunachal Pradesh; known only from the type and its adjacent locality (Map 1).
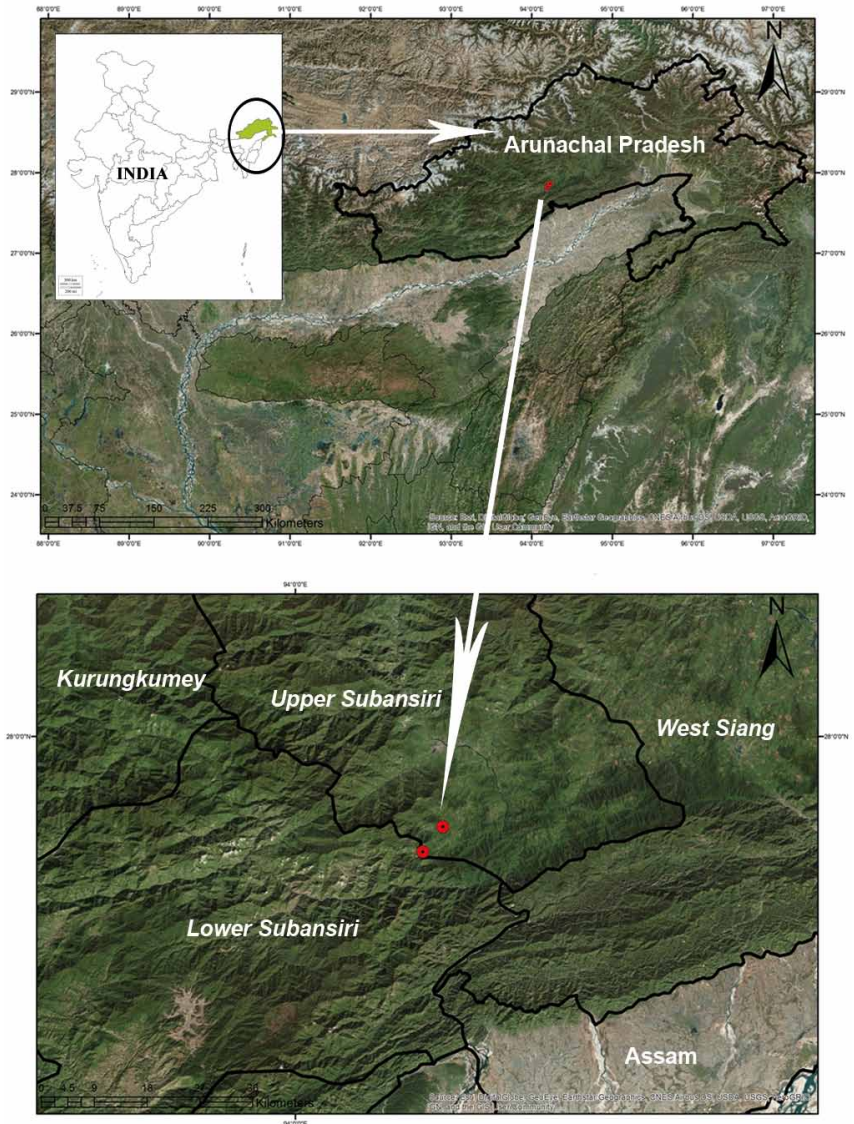

Map 1 Map showing place of collection of Rubus ramachandrae from Upper Subansiri district, Arunachal Pradesh, India.

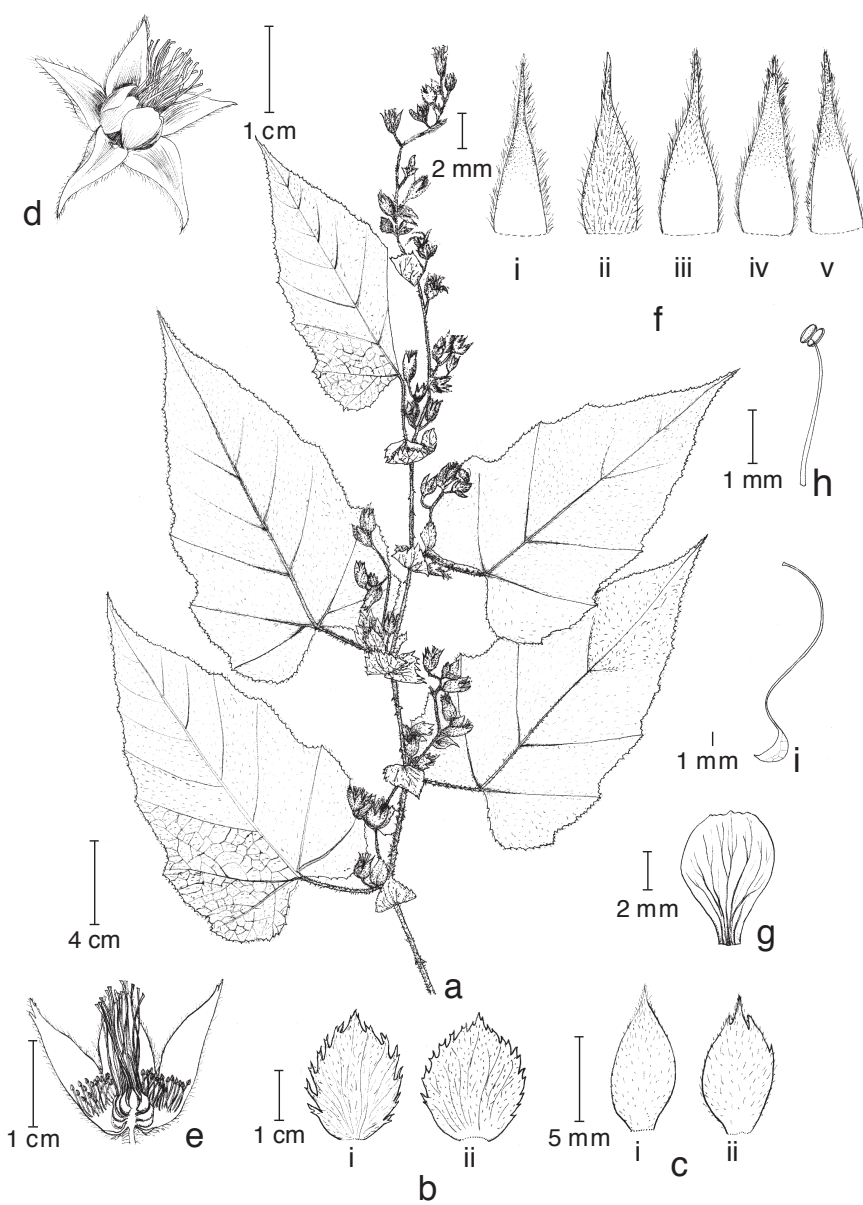

Fig. 2 Rubus ramachandrae S.S.Dash \& Chand.Gupta. a. Flowering twig; b. abaxial surface of stipules; c. abaxial surface of bracts (i: margin serrated near apex, ii: margin entire); d. flower; e. longitudinal section of flower; f. free lobes of calyx (i-iv. adaxial surface; v. abaxial surface); g. petal; h. stamen; i. pistil. - Drawn by Chandani Gupta. 

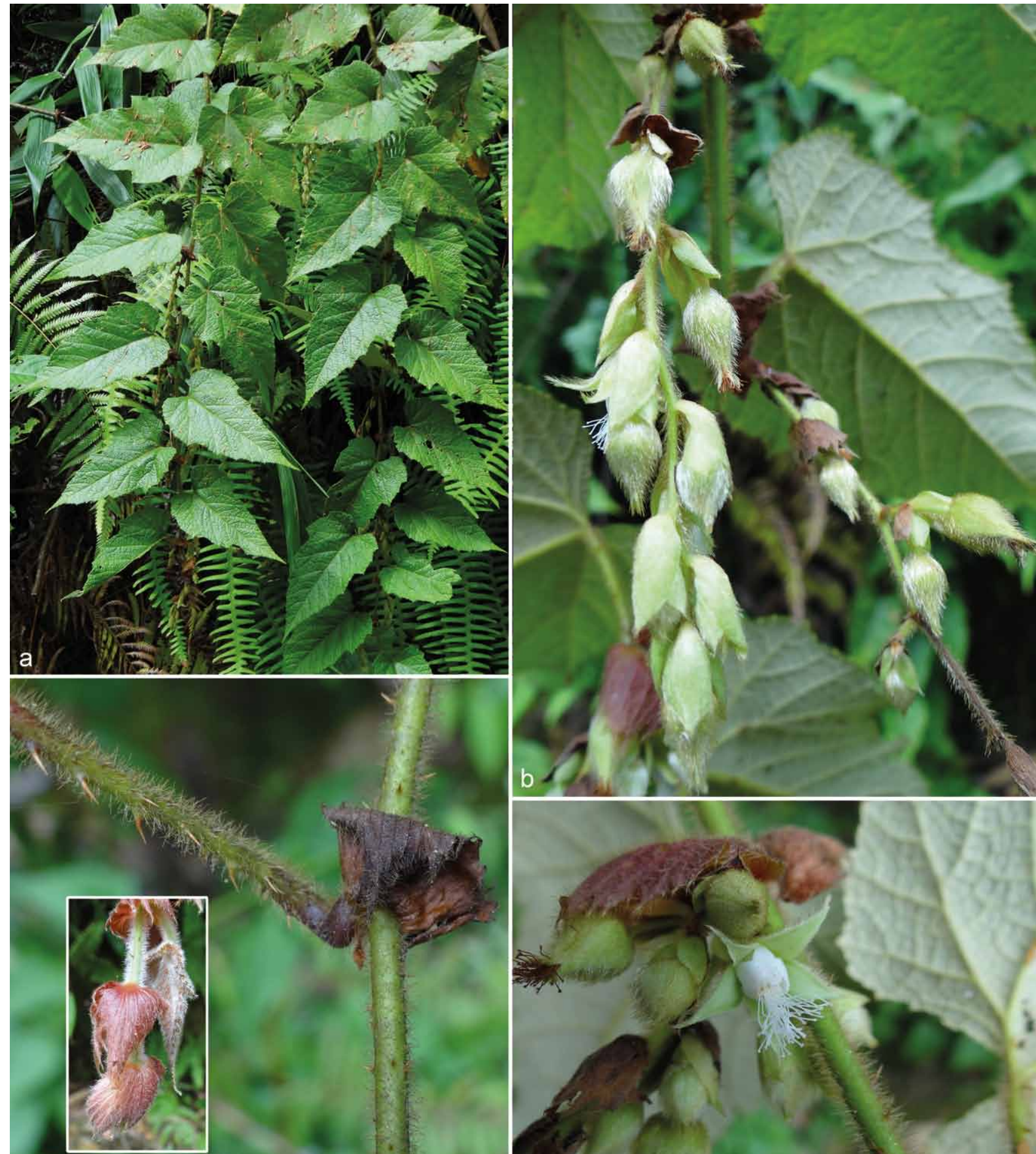

C

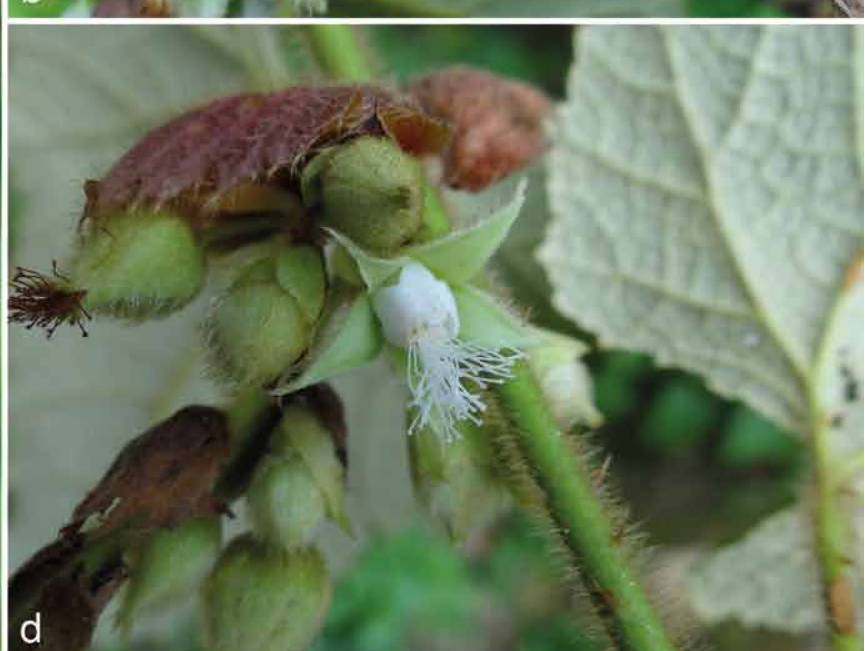

Fig. 3 Field photographs of Rubus ramachandrae S.S.Dash \& Chand.Gupta. a. Habit; b. inflorescences; c. stipules (inset: juvenile stipule); d. closer view of flower. - Photos by S.S. Dash.

Habitat \& Ecology - Rubus ramachandrae grows in open subtropical forests between 1100 and $1300 \mathrm{~m}$.

Flowering \& Fruiting - July to September.

Provisional IUCN conservation assessment - Rubus ramachandrae is known only from two localities in Upper Subansiri in Arunachal Pradesh, India. During our study, we located only two gregarious patches $5 \mathrm{~km}$ apart with 4 or 5 mature plants each. The species has not been collected elsewhere, hence, its provisional conservation status may be considered Data Deficient (IUCN 2017).

Note - Due to the presence of straggling shrubby habit, free stipule, simple leaves, with both needle shaped and reflexed prickles, various forms of panicled axillary and terminal inflorescences and the more or less bell-shaped or campanulate calyx, it is proposed here that $R$. ramachandrae be placed in Rubus subg. Malachobatus Focke (Focke 1910: 41), a subgenus of about 115 species (Focke 1910, 1911, 1914, Kalkman 1993, Lu \& Boufford 2003) mainly concentrated in tropical and subtropical regions of the Asian continent.

Acknowledgements We thank Dr. P. Singh, Director of the Botanical Survey of India (BSI) for encouragement and for providing facilities and Dr. V.K. Rawat and Dr. Manish Kandwal (scientists, Arunachal Pradesh Regional Centre, $\mathrm{BSI}$, Itanagar) for logistic arrangements during the field trip. 

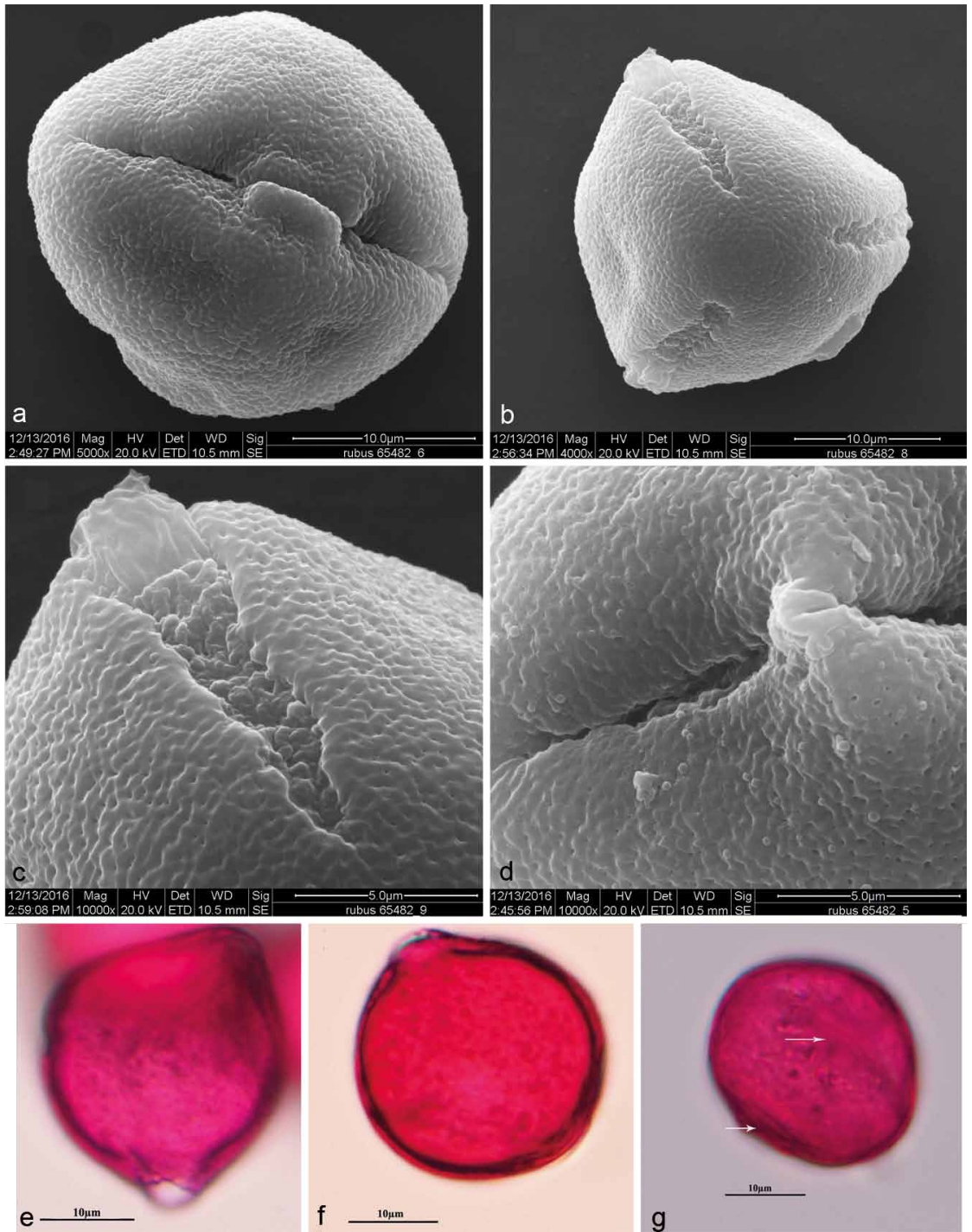

Fig. 4 Pollen morphology of Rubus ramachandrae S.S.Dash \& Chand.Gupta. a-d: SEM images; e-g: LM images. a. Equatorial view of pollen; b. polar view of pollen showing tricolporate aperture; c. closer view of aperture showing endoaperture and the surface ornamentation; $d$. closer view of aperture with bridge; e, f. subpolar view showing endoaperture with bridge; g. subequatorial view (arrow showing colporate aperture).

\section{REFERENCES}

Boufford DE, Siwakoti M, Pendry CA. 2011. Rubus L. In: Watson MF, Akiyama $\mathrm{S}$, Ikeda H, et al. (web-ed. 2), Flora of Nepal. The Royal Botanic Garden, Edinburgh, UK. [Updated version available online at floraofnepal.org, last accessed on 3 Jan. 2017.]

Chowdhery HJ, Giri GS, Pal GD, et al. 1996. In: Hajra PK, Verma DM, Giri GS (eds), Materials for the Flora of Arunachal Pradesh (RanunculaceaeDipsacaceae) vol.1. Botanical Survey of India, Calcutta, India.

Chowdhery HJ, Wadhwa BM. 1984. Rosaceae. In: Chowdhery HJ, Wadhwa BM (eds), Flora of Himachal Pradesh Analysis 1: 234-261. Botanical Survey of India, Calcutta, India.

Erdtman G. 1943. An introduction to pollen analysis. The Chronica Botanica Company, Waltham, USA.

Erdtman G. 1952. Pollen morphology and plant taxonomy of angiosperms. Almqvist \& Wiksell, Stockholm, Sweden.

Focke WO. 1910. Species Ruborum, Monographiae generis Rubi Prodromus part I. Bibliotheca Botanica 17: 1-120.

Focke WO. 1911. Species Ruborum, Monographiae generis Rubi Prodromus, part II. Bibliotheca Botanica 17: 121-223.

Focke WO. 1914. Species Ruborum, Monographiae generis Rubi Prodromus, part III. Bibliotheca Botanica 19: 224-498.

Gupta C, Dash SS. 2015. Rubus sengorensis (Rosaceae): A new record to India from Arunachal Pradesh. Nelumbo 57: 50-55. https://doi.org/10.20324/ nelumbo/v57/2015/87087.

Gupta C, Dash SS, Brach AR. 2016. Lectotypification of two names in the genus Rubus L. (Rosaceae). Phytotaxa 266 (4): 297-300.

Hooker JD. 1878. Rosaceae. In: Hooker JD (ed), The Flora of British India 2: 307-348. London, UK.
IUCN. 2017. Guidelines for using the IUCN Red List categories and criteria. Version 12. Prepared by the Standards and Petitions Subcommittee. Downloadable from http://www.iucnredlist.org/documents/RedListGuidelines.pdf.

Kalkman C. 1993. Rosaceae. In: Flora Malesiana, Ser. I, 11 (2): 227-351. Leiden.

Kanjilal UN, Kanjilal PC, Das A. 1922. Flora of Assam, Vol. 2. Government of Assam, India.

Kuntze CEO. 1879. Methodik der Speciesbeschreibung und Rubus Monographie. Leipzig, Germany.

Linnaeus C. 1753. Species Plantarum 1: 492. Holmiae, Sweden.

Long DG. 1987. Rubus L. In: Grierson AJC, Long DG (eds), Flora of Bhutan

1 (3): 543-562. Royal Botanic Garden, Edinburgh, UK.

Lu LD, Boufford DE. 2003. Rubus L. In: Wu ZH, Raven PH (eds), Flora of China 9: 195-286. Science Press, Beijing and Missouri Botanical Garden Press, St. Louis, USA.

Naruhashi N. 1980. Morphology of 34 Japanese Rubus species. Acta Horticulturae 112: 177-181.

Punt W, Hoen PP, Blackmore S, et al. 2007. Glossary of pollen and spore terminology. Review of Palaeobotany and Palynology 143: 1-81.

Roxburgh W. 1832. Flora Indica, Vol. 2. Serampore, India.

Sharma BM, Kachroo P. 1981. Flora of Jammu and plants of neighbourhood, Vol.1. Bishen Singh Mahendra Pal Singh, Dehradun, India.

Smith JE. 1819. Rubus. In: Rees A (ed), Rees's Cyclopedia, 30. Rubus no. 1-56. London, UK.

Yu TT, Lu LT 1982. Taxa Nova Rosacearum Sinicarum IV. Acta Phytotaxonomica Sinica 20 (4): 453-464. 